\title{
Ecosublimity in Lloyd Jones's Mister Pip
}

\author{
Sathyabhama Daly \& Stephen Torre
}

\author{
James Cook University
}

\begin{abstract}
Literature is the ideal medium for understanding the creative flow of energy that occurs through reading and the way in which it may provide interpretations of culture, language and the creative imagination. This paper analyses Lloyd Jones's novel, Mister Pip (2006), from an ecosublime perspective of the crucial link between place, literature, and the creative imagination in mediating transformations of culture and identity. In Mister Pip, Lloyd Jones explores subtle ways in which literature mediates personal and cultural transformations through the unspoken and invisible and through voices of places and habitus. The setting is Bougainville in 1990 at the height of Papua New Guinea's blockade of the beautiful, but copper -mine dependant, island. The physical setting of the novel plays a major role in the plot, with the jungle environment and military metaphors of conquest used to narrate the chaos and terror following the blockade. The awe and terror of the physical destruction of the environment is offset by the power of the creative imagination to provide an escape from the nightmare world of the physical and psychological destruction wrought by the blockade. Told through the eyes of a young native girl, Matilda, Mister Pip is a stunning portrayal of an island at the mercy of outside forces. With all western contact withdrawn, the one remaining white man, Mr Watts, re-opens the school to restore hope to the villagers. Unqualified and armed with only a copy of Charles Dickens's Great Expectations, he begins to narrate the story of Pip to the children, and through this narration Matilda finds a friend in Pip. This paper will discuss how Lloyd Jones uses the creative space of literature to explore the personal and cultural transformations of a society besieged by a repressive political regime.
\end{abstract}

$\mathrm{M}$ ister Pip is set during the years of the Bougainville secession struggle. It is narrated by a fourteen-year-old islander, Matilda, who presents the events over a three-year period from 1990-1993, when she escapes from the island. The central storyline tells of the lives of the inhabitants of a small village, as they negotiate the shortage of goods caused by the blockade placed on Bougainville by the Papua New Guinea government, the attacks on their village by the 'redskins' (PNG soldiers who were supported by the Australian Government of the time), and the rebels or 'rambos'. The rambos are the alienated young men of the villages engaged in guerrilla warfare with the redskins: "They were our boys but there were no faces in that lot that we knew" (MP 137). Against this background, and to counter the rising fear and despair, the island's one white inhabitant, Mr Watts, re-opens the dilapidated schoolhouse, and runs daily classes in which the students are read passages from Charles Dickens's Great Expectations. The world of literature and the creative imagination enables Matilda and the community to tolerate the atrocities inflicted by the military invasion of their island lifestyle, and the community disintegration that results from the conflict between the soldiers and the rebels.

Lloyd Jones uses the military metaphors of conquest to describe the natural environment and the repressive political regime that subjugate the people. Metaphors of a tropical idyll, of "beach palms spreading up to a blue sky" and "a turquoise sea” are juxtaposed with the terror 
of the "redskins gunboats" menacing the coastline (MP 17). Bougainville prior to the blockade is a place of abundance and growth: "Bougainville is one of the most fertile places on earth. Drop a seed in the soil and 3 months later it is a plant with shinning green leaves. Another 3 months and you'll be picking its fruit” (MP 12). The idyll of the place is also captured in Matilda's description of her first day back at school, as she gazes out of the dilapidated classroom: "I counted three three-lime green geckos and a pale one on the ceiling” (MP 17). But the disjunction between the awe and terror of the environment is evident when she says, "A flower-pecker bird flew in the open window and flew out again. That got our attention because if we had been ready with a net we could have eaten it" (MP 17). The verdant landscape, therefore, is presented as idyllic and as threatening and hostile because without cultivation the bush can just as easily "march down the steep hillsides and bury [the] villages in flower and vine" (MP 12). The destructive effects of the strangler vine mimics the destruction wrought on the environment when the redskins march into the villages, causing death, destruction, and disintegration of the village life.

The metaphor of violence is evident in the description of the military power of the redskins, who hover over the villages like "giant dragonflies, peering down at the clearing" (MP 31). The sound of the helicopter blades slice through the air, warning the villagers of the soldiers' imminent arrival. The villagers flee to the safety of the jungle in abject terror of the anticipated violence: "Everywhere in the shadows I see sweating faces. We tried to blend in with the stillness of the trees" (MP 34). The redskins vent their anger on the mangy dogs, roosters and livestock: "Chooks and roosters sprawled on their swollen sides. . . The same machete blows that took their heads cut down washing and garden stakes” (MP 34). When the helicopters depart, the villagers return faced with the constant fear of the next attack: "The helicopters had gone but we were left with our fear. We didn't know what to do with it (MP 31). The political environment mimics some aspects of the tropical night: "In the tropics night falls quickly. There is no lingering memory of the day just been. . . If you're not ready with candles and kerosene lamps the quick fall of night is like being put away in a dark cell, from where there is no release until the following dawn” (MP 20). For Matilda and the villagers, the soldiers' entry into the village is like the darkness of nightfall, of being trapped in a dark world of terror and chaos, of being abandoned by the civilised world.

In "Literature and Ecology: An Experiment in Ecocriticism", William Rueckert says, "It is perhaps true that the life of the human community depends upon the continuous flow of creative energy (in all its forms) from the creative imagination and intelligence, and that this flow could be considered the sun upon which life in the human community depends” (109). In Mister Pip, the power of literature to give voice to a disempowered society is exploited through the character Mr Watts. Initially, Mr Watts is portrayed as an alienated, tragic/comic character nicknamed "Pop Eye" (MP 1) who is ridiculed by the community; however, he becomes the hero when he stays on to become the school teacher when all others had deserted the island. As the school teacher with limited knowledge of the scientific or mechanical world, Mr Watts is an authority on Dickens (MP 24), and it is his quiet voice and his narration of Great Expectations that enable the children to enter into the creative and imaginative space of literature, and for a short period forget the atrocities of war: "During the blockade we could not waste fuel or candles. But as the rebels and redskins went on butchering one another, we had another reason for hiding under the cover of night. Mr Watts had given us kids another world to spend the night in” (MP 20). In Pip, Matilda finds a friend who will sustain her through the nightmare of the blockade: "I felt like I had been spoken to by this boy Pip. This boy who I couldn't see or touch but knew by ear. I had found a new friend” (MP 20). She had not found this friend in her natural environment: "[N]ot up a tree or 
sulking in the shade, or splashing around in one of hill streams, but in a book. No one had told us kids to look there for a friend" (MP 20). It is the silence and solitude of the world created by Mr Watt's reading of Great Expectations that enables Matilda to escape the noise and terror of a community threatened with disintegration: "Our only consolation was that by reading it a second and third time we would still have another country to flee to. And that would save our sanity" (MP 81). Mr Watts' message to the children as the conflict becomes more brutal is to resist dehumanisation through the power of the imagination: "We have all lost our possessions and many of us our homes ... But these losses, severe though they may seem, remind us of what no person can take, and that is our minds and our imaginations" (MP 107).

Mr Watts by introducing the children to the another world, a world far removed from their own and in a language that they were not familiar with, teaches them about the power of the creative space of literature to bring about cultural and personal transformation. In the novel, this is depicted through the metaphor of the orphan. As Mr Watts says in defence of literature to Matilda's mother, Dolores: "Pip is an orphan who is given a chance to create his own self and destiny. Pip's experience also reminds us of the emigrant's experience. Each leaves behind the place they grew up in. Each strikes out on his own. Each is free to create himself anew" (MP 78). Lloyd Jones's use of the story of the orphan's search for parents and identity parallels not only Mr Watts' life when he takes on the persona of Mr Pip, but also Matilda's life, and life of the Bougainville community, which has been exploited for its copper but has gained no community development from it. It too is a political orphan, subject to exploitation. Learning about life in another place in another era, helps to teach the villagers about universal ideas of struggle and identity - that they are not the only ones trying to preserve a self in face of obliterating forces.

Literature can be a subversive tool in colonising minds, and the cultural 'otherness' of Great Expectations is exemplified through the animosity Dolores, Matilda's mother, has for $\mathrm{Mr}$ Watts, whom she sees as a "shining cuckoo" (MP 41) — the coloniser who controls her daughter's thoughts and actions. Matilda understands her mother's jealousy and fear stem from her mistrust of white men: "She saw only a white man. And white men had stolen her husband ... White men were to blame for the mine and the blockade” (MP 42). Dolores seeks to break Mr Watts' power over her daughter. As Matilda says, "She didn't want me to go deeper into the other world. She is worried she would lose her Matilda to Victorian England" (MP 30). Dolores is afraid that her daughter will reject the oral culture of her society for the literature of the coloniser. Furthermore, the rivalry between Dolores and $\mathrm{Mr}$ Watts stem from the universal moral messages about good and evil, about God and the devil. Dolores's moral values are derived from a religious belief in God, and she is afraid that $\mathrm{Mr}$ Watts will corrupt her daughter's mind with his ethical values derived from literature. $\mathrm{Mr}$ Watts is a sceptic, and Dolores a pragmatist, whose utilitarian perspective is that literature cannot be used to "hook a fish or peel a banana" (MP 128). Dolores admonishes Matilda for her blind faith: "His [Mr Watts] ignorance makes him a dangerous man. And you, Matilda, why do you look to an ignorant, dangerous man for a teacher? This is how crazy the world has become” (MP 115).

The rift between Matilda and her mother is also a theme of adolescence, of challenging parental beliefs and affirming one's values. The conflict between the voice of literature and Dolores' moral view forces Matilda to choose between her mother and Mr Watts: "Even though I lay next to her, in the dark my silence placed me at a distance she could not reach. . . 
Her daughter who resented her, not only for what the neighbours had lost, but for the blame placed at Mr Watts' door. If I had been willing or able to break my silence I would have thrown her own language back at her. I would have said the devil had gotten into her" (MP 98). Matilda is torn between the ethical behaviour of her teacher and her mother's religious beliefs.

Mr Pip also foregrounds the liminal space occupied by literature in a hostile world of political conflict. The classes are disrupted by the redskins and rambos who raid the villages for food and medical supplies. The military aggressions of the redskins cause death and destruction but the novel accentuates the subtle way through which literature affirms the children's sense of identity and place. "In Beyond Ecology: Self, Place and the Pathetic Fallacy", Neil Evernden says that the "act of naming may itself be a part of the process of establishing a sense of place" (101). Mr Watts breaks the psychological power of the redskins over the children by asking them to close their eyes and recite their names. The recitation of her own name empowers and accentuates Matilda's identity and self: "The sound of my voice took me to a place deep inside my head. I already knew that words could take you into a new world, but I didn't know that on the strength of one word spoken for my ears only I would find myself in a room that no one else knew about” (MP 108). The act of naming grounds voice and identity in a dysfunctional world. The soldiers and rebels may alter the physical landscape but the stories provide a haven for Matilda and the children: "Now Mr Watts have given us all another room to lounge around in" (MP109). Mr Watts asks the children to remember fragments of the stories, and they put it together: a weaving together of narrative as written and remembered: "Once I began to turn up fragments of Great Expectations it was surprising where and when I found them. . . I might be gazing out to sea . . . and then without warning, I would find myself with Pip walking up to Satis House with its cobwebs and gloom, and its determination to look backwards” (MP110). In the novel, the interplay between written literature and the oral tradition is emphasised through the respect Mr Watts has for the village elders, who are invited into the classroom to tell their stories. The literary narrative of Great Expectations does not destroy the village culture and tradition, but instead serves to impress upon the children the power of language and literature to bring about cultural transformation of self and identify.

The life-affirming values and individual and community-building influence of story are acutely evident in contrast to those who have not had its benefit. The two other groups who come into the contact with the villagers are the rebels and the redskins. The redskins make three visits to the village, each time increasing their terrorisation of the villagers. They have seen the name of Dickens's character Pip written in the sand, and having completed a census of the village interrogate the people as to the whereabouts of him. Given their illiteracy they cannot comprehend that Pip is a 'character in a book' especially when the book cannot be produced. Dolores had hidden the book because she was jealous of Mr Watts' influence over her daughter's imagination:"Her silence was meant to destroy Pip and the standing of $\mathrm{Mr}$ Watts, a godless white man who would seek to place in her daughter's head a make-believe person with the same status as her kin" (MP 94). It is an act that has reverberating consequences. The redskins burn the villagers' possessions as a warning to them to cooperate in future. On a second visit, when Pip can still not be produced they burn the villagers' huts. In all of these shocking and brutal events, the redskins are revealed as damaged individuals. They abuse women and children, they murder and mutilate: "Their faces looked drained. I now know what kind of person those blank faces are attached to. Their mouths were irritable and sour. They hardly looked at us (MP 172). The redskins' leader is descried: “Once more I 
saw how yellow and bloodshot his eyes were. How sick with malaria. How sick of everything he was. How sick of being a human being” (MP 179). Even the sons of the villagers who have entered the jungle to become rebels sour and degrade in the absence of story. Fixated on their one military purpose they have become alienated even from their own families: when they enter the village seeking medicines and respite, there are uneasy tensions and fears that they will want to rape the young women, that they will become drunk and unruly. Their behaviour contrasts with that of the 'moral person' as evinced in both Mr Watts and Matilda's mother-a humanity that has been learned and enhanced through story. It is $\mathrm{Mr}$ Watts' decision to entertain the rambos with his life story, which is fanciful blend of his own life, his reading, Great Expectations, and the stories of the villagers that enables them to regain some of their human sociability.

The power of narrative to bring about cultural transformation is given voice through $\mathrm{Mr}$ Watts, when he takes on the role of storyteller in order to defuse the violence caused by the political conflict. He tells the rambos, "In a sense you're asking me for my story. . . I have two conditions. One I do not want to be interrupted. Two, my story will take several nights. Seven nights in total" (MP 142). Matilda describes it as "his Pacific version of Great Expectations. As with the original, Mr Watts' version was also serialised, parcelled out over a number of nights with a deadline in mind" (MP150-151). As the spokesperson for the community, Mr Watts embellishes Dickens's narrative, with his own story and with the oral stories of the inhabitants of Bougainville. The recitations of these stories are weaved in with the readings of Great Expectations. Rather than aiding the disintegration and disempowerment of the islanders and their culture, the narrative empowers their sense of identify and culture.

Literature as mediating the transformation of culture and identity is the narrative that $\mathrm{Mr}$ Watts employs in the retelling of his personal history. His story is of the orphan's loss, of having no history or knowledge of his parents; however, his narration emphasises how the birth of his daughter accentuated his self and identity: "But in that baby's face I thought I saw my dead parents emerge. . . I saw bits and pieces of Anglo-Welsh heritage in a coffeecoloured skin. Between us, me and Grace had created a new world” (MP 148). Watts' photographic recall of his daughter's face makes Matilda long to see her own reflection in order to see if she can identify her parents' features in her own face (MP148). It creates a desire of longing to see her absent father. Through the story of Sarah, Mr Watts entraps his listeners: the children, the villagers, and the rambos in the imaginative space of literature. This imaginative space is articulated through the metaphor of the spare room, "an entirely new space” (MP154), which is a creation of Mr Watts' imagination. Matilda, in her role as translator of the stories, uses the same creative and generative metaphors when she defines the spare rooms as "a womb to be filled, a hull to fill with fish" and as "a coconut hollowed out of its white flesh and milk" (MP 154). The metaphor of the spare room articulates the regenerative power of the imagination and of literature in foregrounding identity and place for a community the outside world had ignored. Through the retelling of Great Expectations to the rambos, the importance of narrative and the oral culture of the islanders are affirmed. Grace writes the names of her relatives on the wall (MP 154), and Mr Watts in his retelling give back to the elders of the village the narratives they brought to the classroom: "And now, to the startled ears of all of us kids, we began to hear all the fragments that our mums and uncles and aunts had brought along to Mr Watts’ class” (MP 155).

Ultimately, the brutality of the redskins and the rambos and the chaos of life in a place where metaphorically “all the clocks have stopped”, as in Miss Havisham's narrative, lead to Watts' 
descent into madness. Matilda says, “He wasn’t making any sense .... I I was worried that Mr Watts had now gotten his characters mixed up, that somehow he had slipped out of Pip and into Joe Gargery's skin” (MP 156). Literature is unable to save Mr Watts, Dolores, or the villagers. This madness is depicted through the behaviour of the redskins and rambos whose humanity have been destroyed by the atrocities they commit in warfare, which is explicitly portrayed in the dismembering of Mr Watts by the soldiers on their third visit to the village and the brutal rape and murder of Dolores (MP 182). The violence and brutality of Dolores's rape and murder are a result of her refusal to compromise her religious beliefs and Mr Watts moral integrity, when she "proclaims herself God's witness to the cold-blooded butchery of her old enemy, Mr Watts (MP181). She sacrifices her life in order that the redskins will not rape and kill her now fifteen year old daughter (MP178). The atrocities are so dehumanising that Matilda, although she escapes to the mainland and is reunited with her father is unable to go back to Bougainville until she journeys back to Mr Watts' homeland, and to England in order to put together a coherent whole of the fragments of the story she had heard and which had kept her sane during the blockade.

In the end, the novel affirms that literature itself cannot save people from atrocities of war, Mr Pip, however, is a subtle yet subversive text that suggests that although it is powerless against the inhumanity perpetuated by oppressive political regimes, it can be used to articulate the truth that refuses to be silent. In Mr Pip this is achieved through the power of the imagination to transcend boundaries and enter another world, another time, in order to survive the real world. As Matilda so aptly says: "I point to the one book that supplied me with another world at a time when it was desperately needed. It gave me a friend in Pip. It taught me you can slip under the skin of another just as easily as your own, even when that skin is white and belongs to a boy alive in Dickens' England. Now if that isn't an act of magic I don’t know what is" (MP200).

\section{Works Cited.}

Evernden, Neil. "Beyond Ecology: Self, Place and the Pathetic Fallacy.” The Ecocriticism Reader: Landmarks in Literary Ecology. Eds. Cheryll Glotfelty \& Harold Fromm. Athens, Georgia: University of Georgia Press, 1996. 92-104.

Jones, Lloyd. Mister Pip. Melbourne: Text Publishing Company, 2006.

Rueckert, William. "Literature and Ecology: An Experiment in Ecocriticism.” The Ecocriticism Reader: Landmarks in Literary Ecology. Eds. Cheryll Glotfelty \& Harold Fromm. Athens, Georgia: University of Georgia Press, 1996. 105-123 